U.S. Department of the Interior

U.S. Geological Survey

U.S. ENVIRONMENTAL PROTECTION AGENCY REGION 1

WASTE MANAGEMENT DIVISION

\title{
Geophysical Surveys near the Charles George Municipal Landfill and Flint Pond, Tyngsboro, Massachusetts
}

By Joseph D. Ayotte, Thomas J. Mack, and Craig M. Johnston

Open-File Report 99-231 


\title{
U.S. DEPARTMENT OF THE INTERIOR BRUCE BABBITT, Secretary
}

\author{
U.S. GEOLOGICAL SURVEY \\ Charles G. Groat, Director
}

The use of firm, trade, and brand names in this report is for identification purposes only and does not constitute endorsement by the U.S. Geological Survey.

For additional information write to:

\section{District Chief}

U.S. Geological Survey

New Hampshire/Vermont District

361 Commerce Way

Pembroke, NH 03275-3718

or through our website at http://nh.water.usgs.gov
Copies of this report can be purchased from:

U.S. Geological Survey

Information Services

Box 25286

Federal Center

Denver, CO 80225 


\section{CONTENTS}

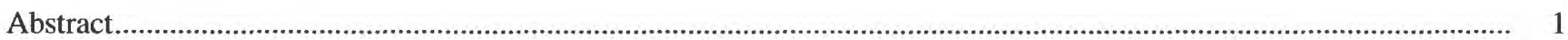

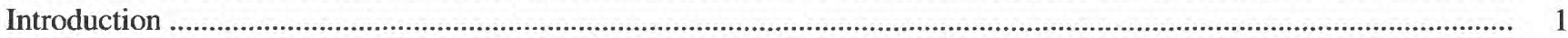

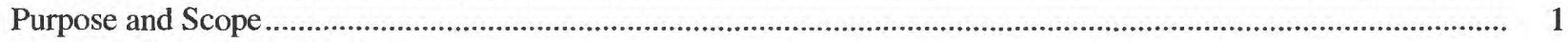

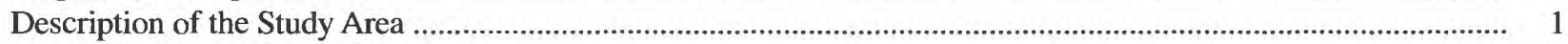

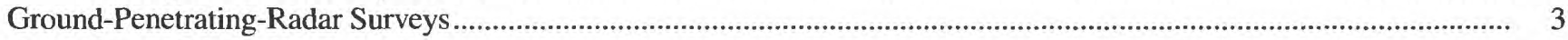

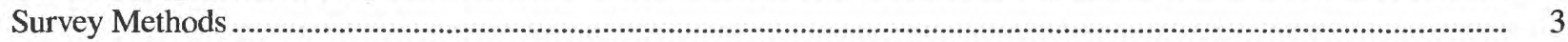

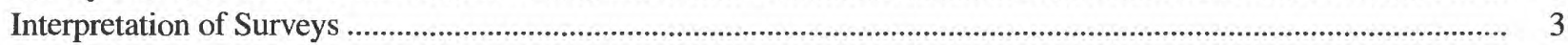

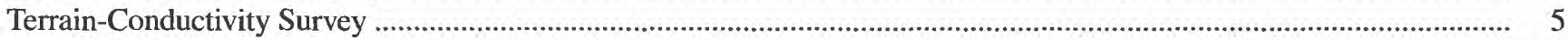

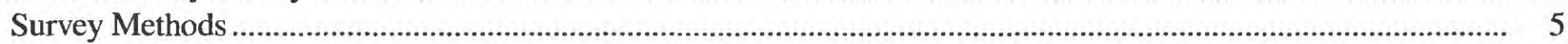

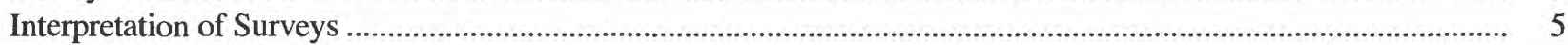

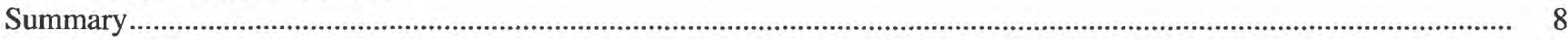

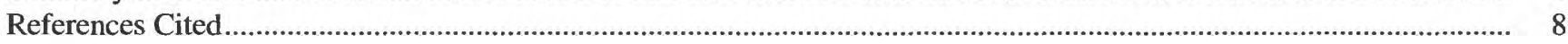

\section{FIGURES}

1-2. Maps showing:

1. Location of the study area in Tyngsboro, Massachusetts....................................................................... 2

2. Locations of geophysical surveys near Charles George Landfill and in Flint Pond ....................................... 4

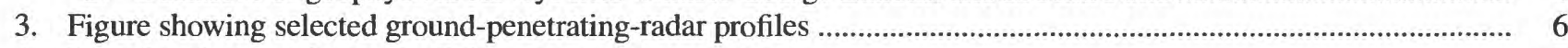

4. Map showing terrain-conductivity survey sites .............................................................................................

\section{CONVERSION FACTORS AND ABBREVIATIONS}

\begin{tabular}{rll}
\hline Multiply & \multicolumn{1}{c}{ By } & To obtain \\
\hline foot $(\mathrm{ft})$ & 0.3048 & meter \\
mile $(\mathrm{mi})$ & 1.609 & kilometer
\end{tabular}

Temperature in degrees Fahrenheit $\left({ }^{\circ} \mathrm{F}\right)$ can be converted to degrees Celsius $\left({ }^{\circ} \mathrm{C}\right)$ as follows: ${ }^{\circ} \mathrm{C}=5 / 9\left({ }^{\circ} \mathrm{F}-32\right)$.

Sea Level: In this report "sea level" refers to the National Geodetic Vertical Datum of 1929 (NGVD of 1929) — a geodetic datum derived from a general adjustment of the first-order level nets of both the United States and Canada, formerly called Sea Level Datum of 1929.

\section{OTHER ABBREVIATIONS USED IN REPORT:}

$\mu \mathrm{S} / \mathrm{m} \quad$ microsiemens per meter at $25^{\circ}$ Celsius

$\mathrm{ft} / \mathrm{ns}$ foot per nanosecond

$\mathrm{MHz}$ megahertz 


\title{
Geophysical Surveys near the Charles George Municipal Landfill and in Flint Pond, Tyngsboro, Massachusetts
}

\author{
By Joseph D. Ayotte, Thomas J. Mack, and Craig M. Johnston
}

\section{Abstract}

Two geophysical techniques were used to provide a preliminary lithologic and waterquality characterization of Flint Pond near the Charles George Municipal Landfill in Tyngsboro, Massachusetts. Ground-penetrating-radar surveys were conducted on the pond, and on some nearby roads, to provide lithologic information. Electromagnetic-terrain conductivity surveys were conducted on the pond surface to provide a preliminary assessment of water quality.

Water depths were less than 5 feet in the study area. The pond bottom consisted of finegrained sediment that generally ranged from less than 1 to about 4 feet thick. Stratified-drift and lake-bottom sediments are estimated to be less than 10 feet thick throughout most of the pond area. At the southern end of the pond, an area of stratified drift is about 35 feet thick. Groundpenetrating-radar data indicate that overburden is thinner at the northern end of the pond than at the southern end.

A large terrain-conductivity anomaly of up to 74 microsiemens per meter was identified at the northern end of the pond. The magnitude and location of the anomaly suggest that it is not likely to be related to the nearby landfill. Terrain conductivities elsewhere in the study area were generally low, less than 10 microsiemens per meter, and did not indicate the presence of a detectable electrically conductive contaminant plume from the landfill.

\section{INTRODUCTION}

Flint Pond in Tyngsboro, Massachusetts, is 1/4 mi downgradient of the Charles George Municipal Landfill (fig. 1). The pond is a recreational resource for the area and is bordered by homes and seasonal camps. The stratified-drift aquifer beneath the southern end of the pond is used for water supply. The extent and potential migration of contamination from the landfill towards the pond is a concern for local residents and those using the pond for recreational activities. The U.S. Geological Survey (USGS), in cooperation with the U.S. Environmental Protection Agency (USEPA), conducted preliminary geophysical surveys during February 1997 beneath the pond, and at some selected sites near the pond and landfill, to assess underlying lithologic conditions and to provide an indicator of ground-water quality.

\section{Purpose and Scope}

The purpose of this report is to present the results of ground-penetrating radar surveys, used to determine aquifer lithology; and terrain-conductivity surveys, used to provide an indicator of ground-water quality in the aquifer beneath Flint Pond. The study was limited to Flint Pond and areas immediately adjacent to Flint Pond and the Charles George Municipal Landfill.

\section{Description of the Study Area}

The study area (fig. 1) consists of Flint Pond, including the surrounding shoreline, and selected areas adjacent to Flint Pond and the municipal landfill. Most of the study area is overlain by glacial till, consisting of an unsorted silty sand. An area of 


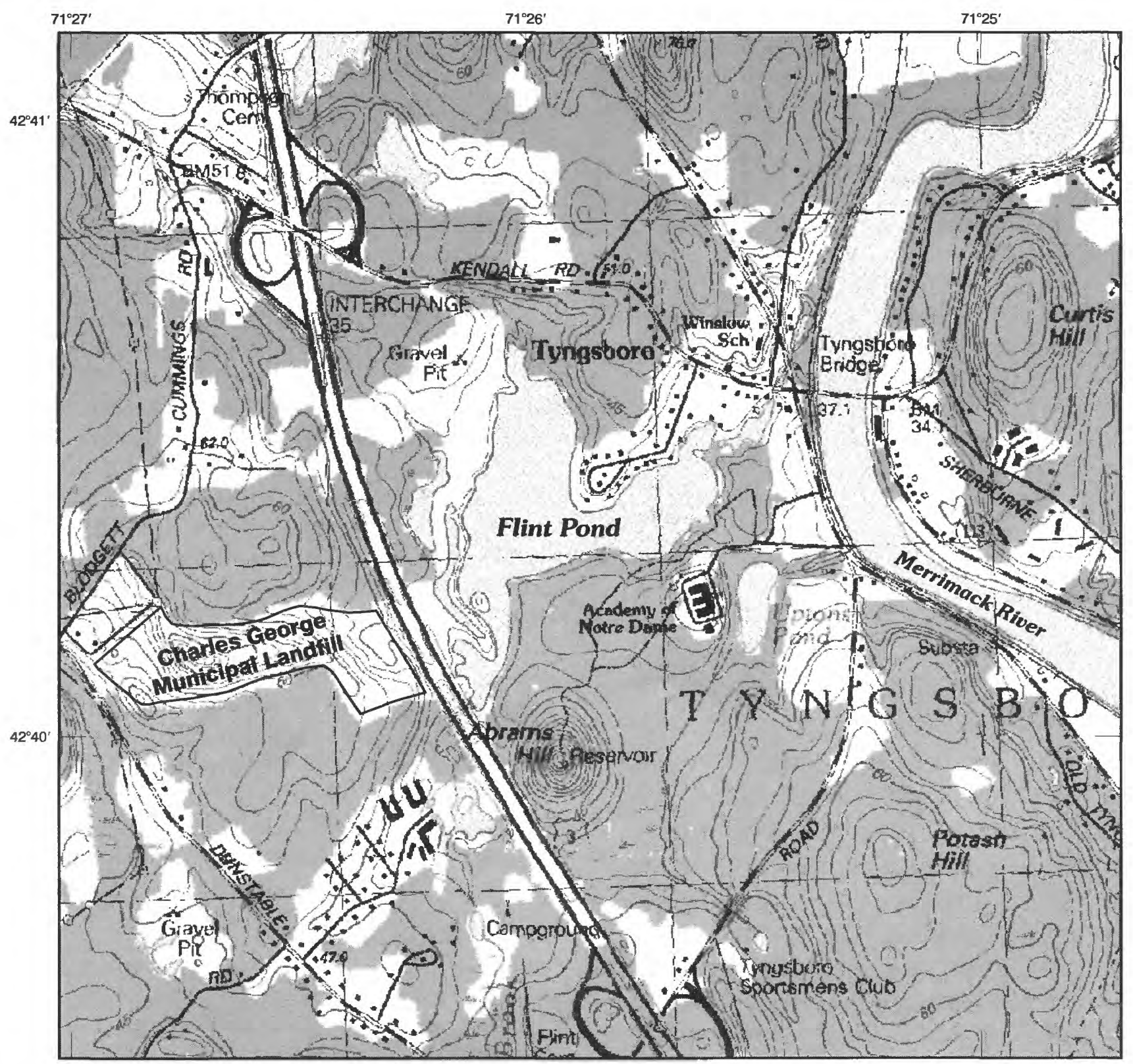

Base from U.S. Geological Survey

Digital raster graph, Lowell, Mass.-N.H.,

$7.5 \times 15$ minute, $1: 25,000,1987$

1,000-meter Universal Transverse Mercator grid, zone 19

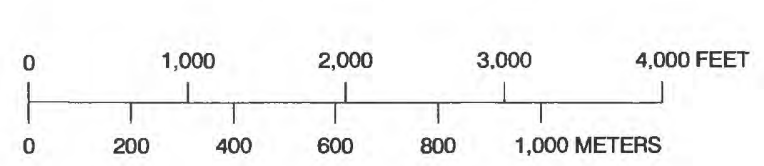

Figure 1. Location of the study area in Tyngsboro, Massachusetts. 
stratified sand and gravel more than $100 \mathrm{ft}$ thick lies between the landfill and the pond (TRC Companies, Inc., 1996). Ice-contact deposits are exposed at the west shore of the pond between the pond and the highway, and outwash sediments are present at the southeastern shore of the pond, near a private academy.

\section{GROUND-PENETRATING-RADAR SURVEYS}

Ground-penetrating-radar (GPR) surveys were conducted on Flint Pond and adjacent areas to provide information on the thickness of glacial stratified drift. The GPR surveys were conducted at the following locations and are identified by profile file number on fig. 2:

1. The wetland at the north end of Flint Pond (F372, F373, F374);

2. The entire shoreline of Flint Pond (file F375, F379, F380, F381, F382, F383, F384);

3. Kendall Road, east past Flint Road (files F6, F7, F8);

4. Dirt road west of the private academy to Route 3 (files F3, F4, F11, F12);

5. Dunstable Road, west side of the Charles George Municipal Landfill (files F9, F10); and

6. Route 3, east side of Charles George Municipal Landfill (file F14).

\section{Survey Methods}

GPR surveys were conducted according to methods described by Beres and Haeni (1991). The GPR-survey system transmits radio-frequency electromagnetic pulses into the ground and receives energy reflected back from subsurface reflectors. Reflectors can be any subsurface contact between geologic materials with different physical and electrical properties, such as the interface between lithologic units or layers within a unit. The surveys were conducted with bi-static $100 \mathrm{MHz}$ center-frequency transmitting and receiving antennas that were towed over frozen pond surfaces and adjacent to selected roads. The profiles can be examined visually to provide indications of lithologic properties. Interpretation of GPR profiles is improved by comparison with lithologic logs.
Beres and Haeni (1991) provide an interpretive guide for various types of typical reflector patterns for unconsolidated deposits. Parallel reflectors indicate the presence of laminated fine-grained sediments, such as lake-bottom sediments observed in this study. Complex, subparallel, and chaotic reflectors generally indicate coarse-grained sediments. Inverted V-shaped reflectors are indicative of point reflectors that could be from cobbles or boulders in till. Near-surface inverted V-shaped reflectors often indicate objects such as buried pipelines, culverts, or conduits.

Transmission velocities of the radar signal were used to interpret depth to a reflector. The approximate velocities of electromagnetic waves are $0.1 \mathrm{ft} / \mathrm{ns}$ in water, $0.3 \mathrm{ft} / \mathrm{ns}$ in organic soils (silt and peat), $0.2 \mathrm{ft} / \mathrm{ns}$ in saturated sand, and $0.4 \mathrm{ft} / \mathrm{ns}$ in unsaturated sand (Beres and Haeni, 1991). The velocity of electromagnetic waves in ice is approximately $0.5 \mathrm{ft} / \mathrm{ns}$. In general, the ice thickness was about $1 \mathrm{ft}$, and thus did not significantly affect the interpretation of depths to subsurface reflectors. Interpretation of GPR profiles, which includes water, organic materials, and saturated sediment, requires the use of multiple depth scales. For any radar frequency, the primary factor limiting depth of penetration is the electrical conductivity of the subsurface materials (Beres and Haeni, 1991); however, high frequencies are attenuated faster than low frequencies. Observations of GPR profiles in New Hampshire (Ayotte and others, 1999) indicate that electromagnetic-radar waves penetrate organic sediments with little attenuation. Electrically conductive materials, such as the clay minerals commonly found in tills, significantly limit radar-signal penetration. Lithologic information obtained from drilling logs was used to confirm interpretations of GPR profiles.

\section{Interpretation of Surveys}

GPR profiles in the study area indicate shallow, unconsolidated deposits underlying most of the areas investigated. The following discussion of depths to reflectors is based on estimates of GPR velocities in typical glacial sediments. Stratified-drift and lakebottom sediments are estimated to be less than $10 \mathrm{ft}$ thick beneath most of the pond, particularly along the perimeter, and water depths were generally less than $5 \mathrm{ft}$. One exception is a buried channel at the south end of the pond, where stratified-drift deposits about 


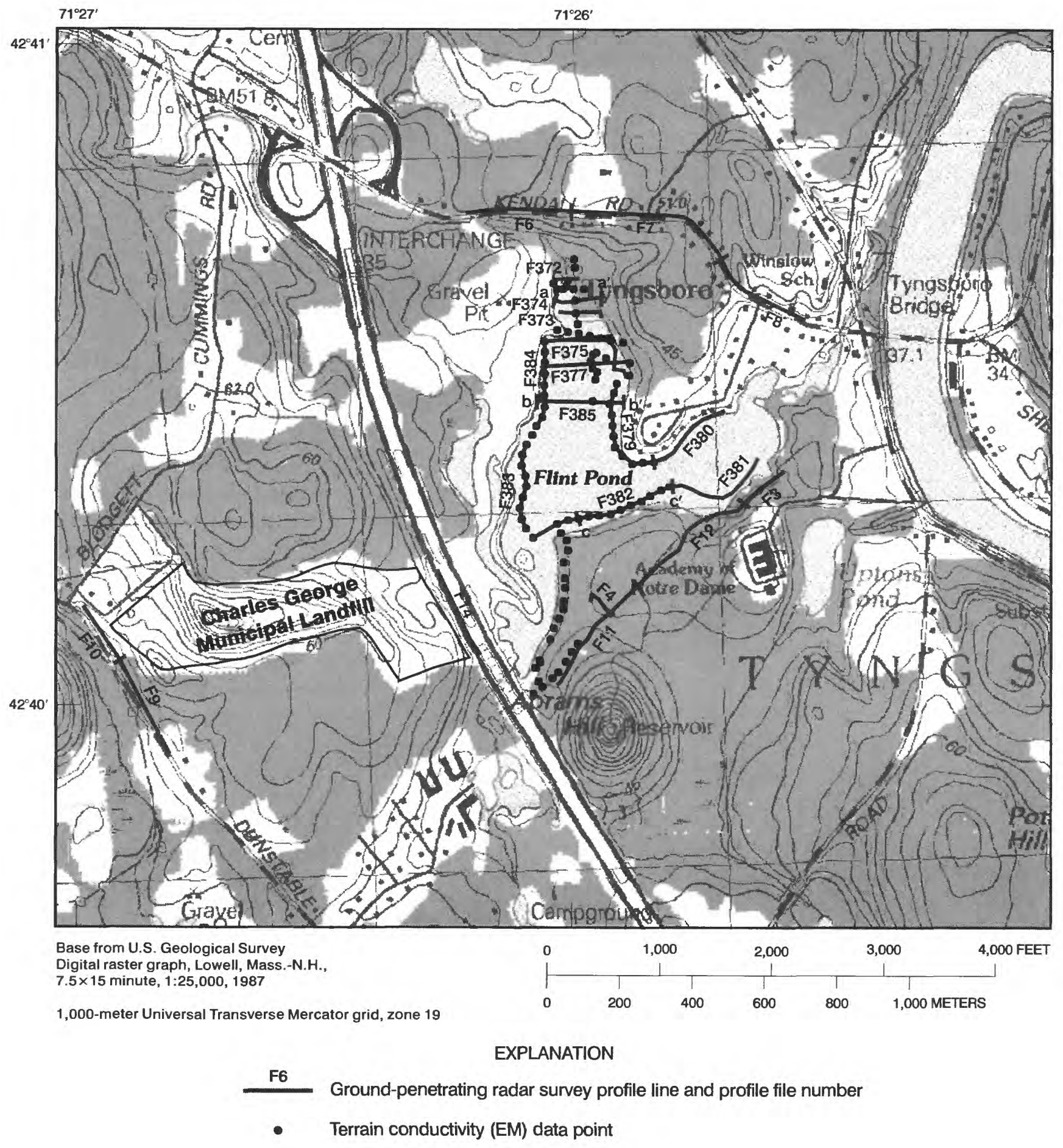

Figure 2. Locations of geophysical surveys near Charles George Landfill and in Flint Pond, Tyngsboro, Massachusetts. 
$35 \mathrm{ft}$ thick were found (fig. $3 \mathrm{c}-\mathrm{c}^{\prime}$ ). The pond bottom consisted of fine-grained sediment that is less than $1 \mathrm{ft}$ to about $4 \mathrm{ft}$ thick. At the northern end of the pond, the buried channel is less prominent, but is about $15 \mathrm{ft}$ thick (fig. 3a-a'). The radar profile shows a change in the reflector response, which could represent the pond bottom and stratified-drift deposits. Similarly, in the middle of the pond, a change in reflector response is seen in figure $3 b-b^{\prime}$, which could represent the bottom of stratified-drift deposits. This surface in fig. $3 b-b^{\prime}$ is deeper than in profile $a-a^{\prime}$ and is approximately 20 to $25 \mathrm{ft}$ thick. No drilling information is available to confirm the GPR results. GPR data indicate that a buried channel could extend the entire length of the pond.

Electromagnetic-wave penetration was limited because the overburden was relatively thin. GPR profiles elsewhere in the study area either showed little-to-no stratified-drift thickness or were otherwise not informative and are not presented. These uninterpretable records were in the southern end of the pond (files F4, F11 and F12), and information collected from the profiles was inconclusive and not presented here because of the chaotic nature of coarse-grained sediments and depths to bedrock, or other stratigraphic changes that exceeded the GPR signal penetration.

\section{TERRAIN-CONDUCTIVITY SURVEY}

An electromagnetic-terrain conductivity survey was conducted to identify a possible ground-watercontaminant plume in glacial sediments beneath Flint Pond. Terrain-conductivity surveys were done on Flint Pond and at selected locations on the shoreline. The surveys consisted of point measurements $100 \mathrm{ft}$ apart, and were located using a high-resolution global positioning system (GPS).

\section{Survey Methods}

A Geonics EM31 was used to measure electromagnetic-terrain conductivity in February 1997, at points along lines on the pond and at selected locations on the shore (fig. 2). The EM31 has an effective exploration depth of about $20 \mathrm{ft}$. The apparent terrain conductivity includes the electromagnetic effects of the sediments and the associated pore water. The glacial sediments (sand and gravel) show little variation at the site; however, the extent of glacial till, which affects terrain conductivity in the study area, is not known.

Ground water associated with contaminant plumes from landfills can have a high specific conductance, (exceeding $1,000 \mu \mathrm{S} / \mathrm{cm}$ ), and can result in apparent terrain conductivities of 10 to $20 \mu \mathrm{S} / \mathrm{m}$. Uncontaminated ground water in nearby southern New Hampshire typically has a much lower specific conductance, about $200 \mu \mathrm{S} / \mathrm{m}$ (Toppin, 1987). In uncontaminated sand- and gravel-aquifer materials, terrain conductivities are typically less than $5 \mu \mathrm{S} / \mathrm{m}$. The conductivity of wetland and lake-bottom sediments in areas of New Hampshire (Ayotte and others, 1999) are relatively low (less than $4 \mu \mathrm{S} / \mathrm{m}$ ) in areas without known contamination. Variation in the apparent terrain conductivity at this site results from variations in the depth of the water column in the lake, the thickness of stratigraphic units, and the groundwater quality.

\section{Interpretation of Surveys}

Terrain conductivities ranged from 1.0 to more than $70 \mu \mathrm{S} / \mathrm{m}$. Low-terrain conductivities, less than $6 \mu \mathrm{S} / \mathrm{m}$, were measured along most of the southern and eastern parts of Flint Pond, indicating generally low conductivity ground water (fig. 4). The lowest readings $(1.0 \mu \mathrm{S} / \mathrm{m})$ were obtained on a trail to the private academy where the water table is more than $10 \mathrm{ft}$ deep and the sediments consist of coarse-grained sands.

Three terrain-conductivity measurements were between 7.4 and $8.8 \mu \mathrm{S} / \mathrm{m}$ near the brook that crosses Route 3 (fig. 4) and flows to the pond. This area is topographically down slope of the municipal landfill and the most likely area to be affected by a contaminant plume. It is not known if these points represent an anomalous conductivity from anthropogenic sources (such as culture or trash) or if this represents the effects of a contaminant plume; however, the three measurements cover an area less than $200 \mathrm{ft}$ wide and are bounded by low-terrain conductivities. These data indicate an isolated, or possibly cultural source for this small area of slightly elevated terrain conductivity rather than a landfill leachate plume.

Slightly higher readings ( 6 to $15 \mu \mathrm{S} / \mathrm{m}$ ) were obtained along the western shoreline of Flint Pond (fig. 4). A terrain conductivity of $15 \mu \mathrm{S} / \mathrm{m}$ was 


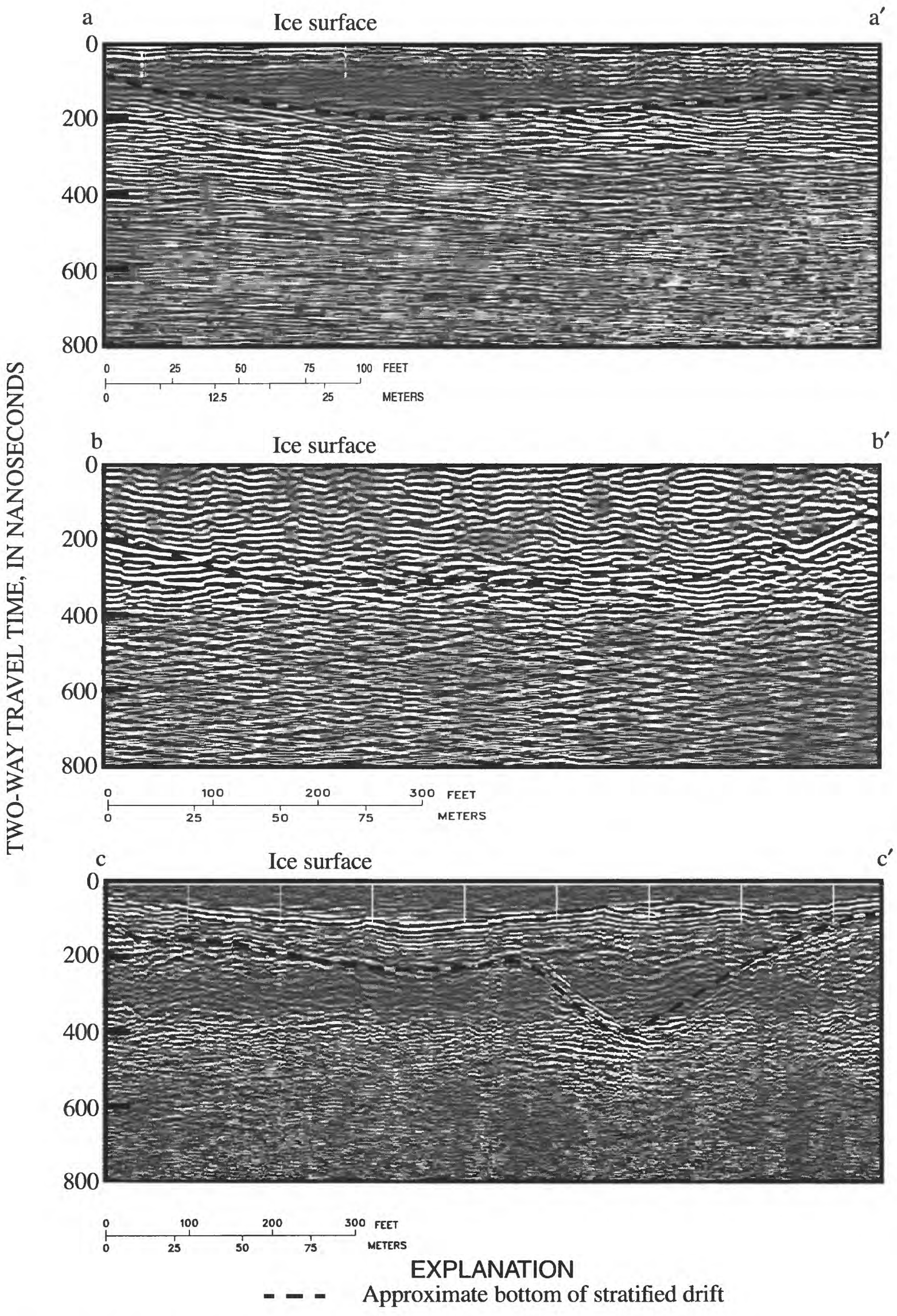

Figure 3. Selected ground-penetrating-radar profiles in Flint Pond, Tyngsboro, Massachusetts. 


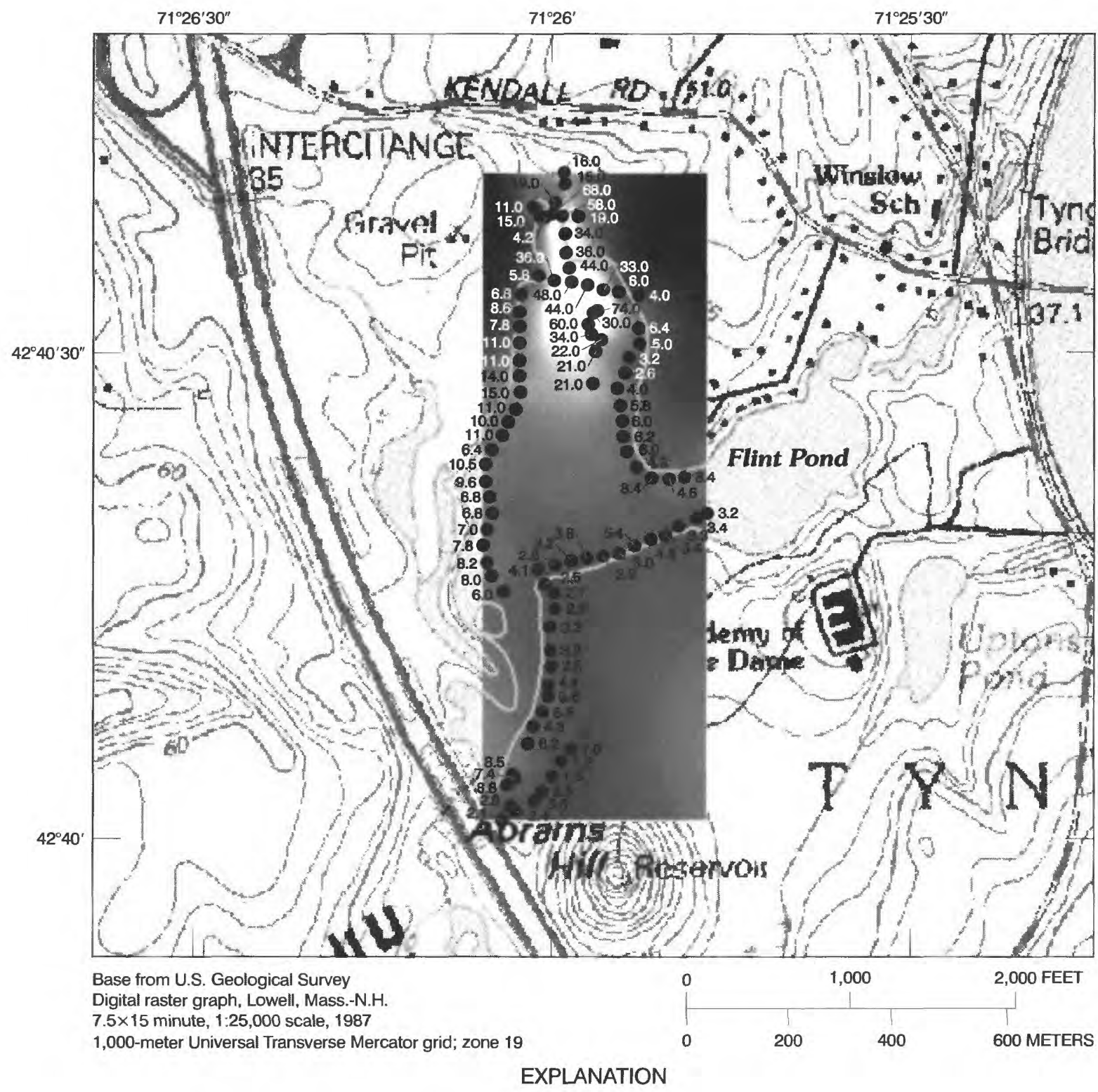

EXPLANATION

Terrain conductivity (EM) data.

Lighter gray shades are areas of higher terrain electrical conductivity.

Darker gray shades are areas of lower terrain electrical conductivity

- 3.2 EM data point and value in millisiemens per meter $(\mathrm{mS} / \mathrm{m})$

Figure 4. Terrain-conductivity survey sites in Flint Pond, Tyngsboro, Massachusetts. 
measured at the middle of the western shoreline of Flint Pond centered in a zone of slightly elevated (greater than $10 \mu \mathrm{S} / \mathrm{m}$ ) terrain conductivity. The landform immediately west of this area appears to be a glacial esker, which should contain relatively coarsegrained, low-terrain-conductivity sediments. It is not known if the origin of this slightly elevated conductivity area is related to an area of high-terrain conductivity at the northern end of the pond.

A large area of high-terrain conductivities (up to $74 \mu \mathrm{S} / \mathrm{m}$ ) was found at the northern end of Flint Pond (fig. 4) where a brook discharges to a nearby wetland. Terrain conductivities in this range are exceptionally high, much higher than the conductivity typically observed for fine-grained sediments. In addition, similar wetland sediments have low-terrain conductivities. Values greater than about $30 \mu \mathrm{S} / \mathrm{m}$ indicate high concentrations of dissolved solids. Such high concentrations are most likely associated with a high ionic solution such as a contaminant plume from salt storage.

\section{SUMMARY}

Ground-penetrating-radar (GPR) surveys at Flint Pond, in Tyngsboro, Massachusetts, indicate that water depths were less than $5 \mathrm{ft}$, and that the lake bottom consists of fine-grained sediment that range in thickness from less than 1 to about $4 \mathrm{ft}$. Estimated thicknesses of stratified-drift and lake-bottom sediments are generally less than $10 \mathrm{ft}$ thick throughout most of the pond area. Results of the GPR surveys indicate that stratified-drift deposits are about $35 \mathrm{ft}$ thick in the southern part and about $15 \mathrm{ft}$ thick in the northern part of the pond.

A terrain-conductivity survey detected a large, high-conductivity anomaly (up to $74 \mu \mathrm{S} / \mathrm{m}$ ) at the northern end of the pond. Based on the magnitude and location of the anomaly, it is not likely to be related to the contaminant plume from a nearby landfill. Terrain conductivities elsewhere in the study area were generally low, less than $10 \mu \mathrm{S} / \mathrm{m}$, and did not indicate the presence of a detectable electrically conductive contaminant plume from the landfill.

\section{REFERENCES CITED}

Ayotte, J.D., Mack, T.J., and Johnston, C.M., 1999, Geophysical surveys of Country Pond and adjacent wetland, and implications for contaminant-plume monitoring, Kingston, New Hampshire: U.S. Geological Survey Open-File Report 99-51, 20 p.

Beres, Milan, Jr., and Haeni, F.P., 1991, Application of ground-penetrating-radar methods in hydrogeologic studies: Ground Water, v. 29, no. 3, p. 375-386.

Toppin, K.W., 1987, Hydrogeology of stratified-drift aquifers and water quality in the Nashua Regional Planning Commission Area, south-central New Hampshire: U.S. Geological Survey Water-Resources Investigations Report 86-4358, 45 p.

TRC Companies, Inc., 1996, Technical support long-term groundwater monitoring Charles George Reclamation Trust Landfill, Tyngsboro, Mass.: Draft Report, October 1996. 


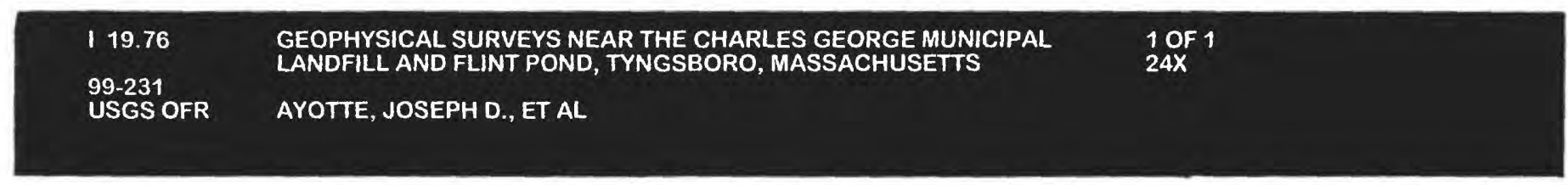

